\title{
A feasibility study on calcareous soil stabilization using polymers in Barka region.
}

\section{Un estudio de viabilidad sobre la estabilización de suelos calcáreos utilizando polímeros en la región de Barka}

\author{
Mohammed Al Jahwari, Satyanarayana.S.V. \\ Department of Civil and Environmental Engineering, National University of Science \\ and Technology, Muscat, Oman
}

Corresponding author: satyanarayana@nu.edu.om

\begin{abstract}
In the Gulf region most of the soils require soil stabilization to increase soil bearing capacity for construction of safe and sustainable buildings. The soils are stabilized either by physical stabilization, chemical stabilization or by mechanical stabilization. The aim of this project is to stabilize calcareous soil in the Barka region with synthetic polymers. The soil samples from the Barka region collected by using standard soil sampling methods. The synthetic polymer was mixed with the calcareous soil in $1 \%, 3 \%$ and $5 \%$. The soil samples were tested for sieve analysis, Atterberg Limit, Particle Density, Proctor test and California Bearing Ratio test before and after addition of synthetic polymer. It was observed that there is a positive impact on the geotechnical properties of soil with the addition of Polymer. The optimum moisture content of the soil reduced and the maximum dry density of the soil increased. The optimum results were found at $5 \%$ addition of polymer where the optimum moisture content was found out to be $12.6 \%$ and the maximum dry density was found out to be $1.997 \mathrm{Mg} / \mathrm{m}^{3}$. The Atterberg limit test to show that the plasticity index of the soil reduced with the addition of polymer and the optimum results were found out at $5 \%$ addition of polymer. Finally, the CBR test results determine that the soil bearing capacity increases with the addition of Polymer. After the addition of $5 \%$ Polymer, the CBR value was found out to be $27.465 \%$ compared to $14.19 \%$ for the fresh calcareous soil. The results are encouraging.
\end{abstract}

Keywords: Atterberg Limit, Calcareous soil, CBR, polymer, stabilization. 
Sustainability, Agri, Food and Environmental Research, (ISSN: 0719-3726), 10(X), 2022: http://dx.doi.org/

\section{RESUMEN}

En la región del Golfo, la mayoría de los suelos requieren estabilización del suelo para aumentar la capacidad de carga del suelo para la construcción de edificios seguros y sostenibles. Los suelos se estabilizan mediante estabilización física, estabilización química o estabilización mecánica. El objetivo de este proyecto es estabilizar suelos calcáreos en la región de Barka con polímeros sintéticos. Las muestras de suelo de la región de Barka recolectadas utilizando métodos estándar de muestreo de suelo. El polímero sintético se mezcló con el suelo calcáreo en $1 \%$, 3\% y 5\%. Las muestras de suelo se analizaron para el análisis de tamices, el límite de Atterberg, la densidad de partículas, la prueba de Proctor y la prueba de California Bearing Ratio antes y después de la adición del polímero sintético. Se observó que existe un impacto positivo en las propiedades geotécnicas del suelo con la adición de Polímero. El contenido óptimo de humedad del suelo se redujo y la densidad máxima seca del suelo aumentó. Los resultados óptimos se encontraron con una adición de polímero del 5\%, donde se encontró que el contenido de humedad óptimo era del 12,6\% y la densidad seca máxima se encontró que era de 1,997 Mg / m3. La prueba de límite de Atterberg para demostrar que el índice de plasticidad del suelo se redujo con la adición de polímero y los resultados óptimos se encontraron al 5\% de adición de polímero. Finalmente, los resultados de la prueba CBR determinan que la capacidad de carga del suelo aumenta con la adición de polímero. Después de la adición de $5 \%$ de polímero, se encontró que el valor de CBR era $27,465 \%$ en comparación con 14,19\% para el suelo calcáreo fresco. Los resultados son alentadores.

Palabras clave: Límite de Atterberg, suelo calcáreo, CBR, polímero, estabilización.

\section{INTRODUCTION}

Construction Industry is one of the fast-growing industries that has been the key to the development and the backbone of the Sultanate of Oman. Barka is about $80 \mathrm{~km}$ from Muscat, the capital city of Oman. In general, Barka has challenging ground layers for infrastructures. In some areas, it contains calcareous soil which is unsuitable for construction, thus a solution must be provided. Traditionally lime and cement have been used for the treatment of this type of soil. However, with the advancement of technology research in this field, polymer use has increased significantly. Polymers have a molecular structure that is made up of similar bonds units that are bonded together with a long chain. Polymers have been used to stabilize soil in recent years, thus this research will be aimed to study the effectiveness of synthetic polymers applied to the soil samples taken from Barka 
Sustainability, Agri, Food and Environmental Research, (ISSN: 0719-3726), 10(X), 2022:

http://dx.doi.org/

region. Synthetic polymers are basically made from petroleum oil. Examples of synthetic polymers include polyester, polyethylene, Teflon and Epoxy. The soil stabilization process with urea-formaldehyde resin yielded better results on soils (Ates 2013).

\section{MATERIALS AND METHODS}

The soil samples were collected from the Barka region and mixed with $1 \%, 3 \%$ and $5 \%$ synthetic polymer. The soil samples were analyzed for different parameters. The Plasticity Index (PI) calculated by using the below formula.

$$
\mathrm{PI}=\mathrm{LL}-\mathrm{PL}
$$

Standard Compaction Test, California Bearing Ratio (CBR) test were conducted as per the standard procedures. The California Bearing Ratio (CBR) values calculated by using the below formula.

California bearing ratio $(\mathrm{CBR})=(\mathrm{PT} / \mathrm{PS}) \times 100$

Where PT = Corrected unit (or total) test load corresponding to the chosen penetration curve,

PS = Unit (or total) standard load for the same depth of penetration as for PS taken from standard code.

The details about the materials are as follow;

Soil sampling: The soil was used in the research project was collected from Barka City that is located around $80 \mathrm{~km}$ from the capital city (Muscat). The soil sample was collected at a depth of $1.5 \mathrm{~m}-2.0 \mathrm{~m}$ with the help of Muscat Lab Company.

A polymer is a chemical compound that is bound together by a long chain of repeating compounds. Polymers can be categorized into natural polymers and synthetic polymers. Natural polymers include wool, DNA, Cellulose, etc. and synthetic polymers include Nylon, Polystyrene, etc. The polymer provides high strength and stability to the soil. It provides high resistance to chemical and it is economical when compared with cement and gypsum. 
Sustainability, Agri, Food and Environmental Research, (ISSN: 0719-3726), 10(X), 2022:

http://dx.doi.org/

\section{RESULTS AND DISCUSSIONS}

Specific Gravity Test (BS 1377): This test aimed to measure the strength and quality of fresh soil samples.Table 1 shows the specific gravity test results that were conducted on 5 samples of fresh soil.

Table 1. Specific Gravity Test

\begin{tabular}{lccccc}
\hline Weights in grams & Sample 1 & Sample 2 & Sample 3 & Sample 4 & Sample 5 \\
\hline Mass of pycnometer -m1 (g) & 464 & 464 & 464 & 464 & 464 \\
Mass of dry soil $(\mathrm{g})$ & 191 & 187.5 & 181.3 & 182.9 & 188.4 \\
Mass of dry soil -m2 (g) & 655.0 & 651.5 & 645.3 & 646.9 & 652.4 \\
Mass of soil+pycnometer+water-m3 (g) & 1726.4 & 1723.3 & 1719.3 & 1720.6 & 1723.9 \\
Mass of pycnometer +water-m4 (g) & 1608 & 1608 & 1608 & 1608 & 1608 \\
Particle Density (G) & 2.63 & 2.60 & 2.59 & 2.60 & 2.60 \\
\hline
\end{tabular}

Atterberg Limit Test: The test is conducted on fresh soil (soils from Barks region), and soils with different percentage $(1 \%, 3 \%$ and $5 \%)$ of polymer.

Table 2. Atterberg Limit Test Results for Fresh Soil from Barka Region.

\begin{tabular}{lcccc}
\hline \multicolumn{1}{c}{ PLASTIC LIMIT } & & 1 & 2 & Average \\
\hline Mass of wet soil + container & $(\mathrm{gm})$. & 21.82 & 22.97 & \\
Mass of dry soil + container & $(\mathrm{gm})$. & 21.20 & 22.30 & \\
Mass of container & $(\mathrm{gm})$. & 18.10 & 19.20 & 21 \\
Mass of moisture & $(\mathrm{gm})$. & 0.62 & 0.7 & \\
Mass of dry soil & $(\mathrm{gm})$. & 3.10 & 3.1 & \\
Moisture content & $(\%)$ & 20.00 & 21.6 & \\
LIQUID LIMIT & & 1 & 2 & 3 \\
Nos. of Bumps & & 12 & 25 & 26 \\
Mass of wet soil + container & $(\mathrm{gm})$. & 95.10 & 95.22 & 94.80 \\
Mass of dry soil + container & $(\mathrm{gm})$. & 86.23 & 87.40 & 86.12 \\
Mass of container & $(\mathrm{gm})$. & 61.80 & 64.60 & 61.10 \\
Mass of moisture & $(\mathrm{gm})$. & 8.87 & 7.82 & 8.68 \\
Mass of dry soil & $(\mathrm{gm})$. & 24.43 & 22.80 & 25.02 \\
Moisture content & $(\%)$ & 36.30 & 34.30 & 34.70 \\
\hline
\end{tabular}


Sustainability, Agri, Food and Environmental Research, (ISSN: 0719-3726), 10(X), 2022:

http://dx.doi.org/

\section{Plastic Limit}

Mass of moisture $=$ (mass of wet soil + container $)-($ mass of dry soil + container $)$

Liquid Limit

Moisture content at 25 blows $=34.3$

- Plasticity Index $=$ Liquid Limit - Plastic Limit $=34.3-20=14.3$ Atterberg Limit Test Results for Soil from Barka Region with 1\% Polymer.

Table 3. Atterberg Limit Test Results for Soil from Barka Region with 1\% Polymer

\begin{tabular}{lcccc}
\hline PLASTIC LIMIT & & 1 & 2 & Average \\
\hline Mass of wet soil + container & $(\mathrm{gm})$. & 21.40 & 22.80 & \\
Mass of dry soil + container & $(\mathrm{gm})$. & 20.90 & 22.20 & \\
Mass of container & $(\mathrm{gm})$. & 18.10 & 18.90 & \\
Mass of moisture & $(\mathrm{gm})$. & 0.50 & 0.6 & 18 \\
Mass of dry soil & $(\mathrm{gm})$. & 2.8 & 3.3 & \\
Moisture content & $(\%)$ & 17.9 & 18.2 & \\
LIQUID LIMIT & & 1 & 2 & 3 \\
Nos. of Bumps & & 14 & 25 & 37 \\
Mass of wet soil + container & $(\mathrm{gm})$. & 95.00 & 94.80 & 94.10 \\
Mass of dry soil + container & $(\mathrm{gm})$. & 86.20 & 87.60 & 86.90 \\
Mass of container & $(\mathrm{gm})$. & 60.90 & 63.80 & 60.60 \\
Mass of moisture & $(\mathrm{gm})$. & 8.80 & 7.20 & 7.20 \\
Mass of dry soil & $(\mathrm{gm})$. & 25.30 & 23.80 & 26.30 \\
Moisture content & $(\%)$ & 34.8 & 30.3 & 27.4 \\
\hline
\end{tabular}

The PI $=(30.3-18)=12.3$ 
Sustainability, Agri, Food and Environmental Research, (ISSN: 0719-3726), 10(X), 2022: http://dx.doi.org/

Table 4. Atterberg Limit Test Results for Soil from Barka Region with 3\% Polymer

\begin{tabular}{lcccc}
\hline PLASTIC LIMIT & & 1 & 2 & Average \\
\hline Mass of wet soil + container & $(\mathrm{gm})$. & 21.40 & 22.90 & \\
Mass of dry soil + container & $(\mathrm{gm})$. & 20.90 & 22.20 & \\
Mass of container & $(\mathrm{gm})$. & 17.60 & 17.40 & \\
Mass of moisture & $(\mathrm{gm})$. & 0.50 & 0.7 & 15 \\
Mass of dry soil & $(\mathrm{gm})$. & 3.3 & 4.8 & \\
Moisture content & $(\%)$ & 15.2 & 14.6 & \\
LIQUID LIMIT & & 1 & 2 & 3 \\
Nos. of Bumps & 15 & 25 & 36 \\
Mass of wet soil + container & $(\mathrm{gm})$. & 95.10 & 94.60 & 94.20 \\
Mass of dry soil + container & $(\mathrm{gm})$. & 86.60 & 88.10 & 87.10 \\
Mass of container & $(\mathrm{gm})$. & 60.20 & 63.80 & 59.80 \\
Mass of moisture & $(\mathrm{gm})$. & 8.50 & 6.50 & 7.10 \\
Mass of dry soil & $(\mathrm{gm})$. & 26.40 & 24.30 & 27.30 \\
Moisture content & $(\%)$ & 32.2 & 26.7 & 26.0 \\
\hline
\end{tabular}

The $\mathrm{PI}=(26.7-15)=11.7$.

Table 5. Atterberg Limit Test Results for Soil from Barka Region with 5\% Polymer.

\begin{tabular}{lcccc}
\hline PLASTIC LIMIT & & 1 & 2 & 3 \\
\hline Mass of wet soil + container & $(\mathrm{gm})$. & 21.10 & 22.70 & \\
Mass of dry soil + container & $(\mathrm{gm})$. & 20.70 & 22.10 & \\
Mass of container & $(\mathrm{gm})$. & 17.60 & 17.40 & 13 \\
Mass of moisture & $(\mathrm{gm})$. & 0.40 & 0.6 & \\
Mass of dry soil & $(\mathrm{gm})$. & 3.1 & 4.7 & \\
Moisture content & $(\%)$ & 12.9 & 12.8 & \\
LIQUID LIMIT & & 1 & 2 & 3 \\
Nos. of Bumps & & 14 & 25 & 38 \\
Mass of wet soil + container & $(\mathrm{gm})$. & 95.20 & 94.80 & 94.20 \\
Mass of dry soil + container & $(\mathrm{gm})$. & 86.50 & 89.10 & 87.60 \\
Mass of container & $(\mathrm{gm})$. & 59.80 & 63.10 & 59.80 \\
Mass of moisture & $(\mathrm{gm})$. & 8.70 & 5.70 & 6.60 \\
Mass of dry soil & $(\mathrm{gm})$. & 26.70 & 26.00 & 27.80 \\
Moisture content & $(\%)$ & 32.6 & 21.9 & 23.7 \\
\hline
\end{tabular}


Sustainability, Agri, Food and Environmental Research, (ISSN: 0719-3726), 10(X), 2022:

http://dx.doi.org/

The table number 6 shows the Atterberg Limit Test results for Soil from Barka Region and $5 \%$ Polymer. The PI $=(21.9-13)=8.90$.

c. Standard Compaction Test (Proctor Test)

This test was done with fresh soil, $1 \%$ polymer, $3 \%$ polymer and $5 \%$ polymer to determine the OMC and MDD values.

Table 6. Standard Compaction Test for fresh soil from Barka Region

\begin{tabular}{lccccc}
\hline Mass of Mold+Base+Soil & 5701 & 5797 & 5879 & 5950 & 5958 \\
\hline Mass of Mold+Base & 3797 & 3797 & 3797 & 3797 & 3797 \\
Mass of Soil & 1904 & 2000 & 2082 & 2153 & 2161 \\
Volume & 988 & 988 & 988 & 988 & 988 \\
Bulk Density & 1.927 & 2.024 & 2.107 & 2.179 & 2.187 \\
Moisture Content \% & 8.1 & 10.8 & 13.1 & 15.3 & 17.8 \\
Dry Density & 1.783 & 1.827 & 1.863 & 1.890 & 1.857 \\
Mass of Wet Soil+Container & 231.1 & 228.4 & 239.4 & 216.2 & 216.7 \\
Mass of Dry Soil+Container & 219.2 & 212.6 & 219.7 & 196.2 & 194 \\
Mass of container & 72.3 & 66.8 & 69.1 & 65.7 & 66.2 \\
Moisture Content & 11.9 & 15.8 & 19.7 & 20 & 22.7 \\
Mass of soil & 146.9 & 145.8 & 150.6 & 130.5 & 127.8 \\
Moisture content & 8.1 & 10.8 & 13.1 & 15.3 & 17.8 \\
\hline
\end{tabular}

According to table number 6 , it was found that the OMC was $15.3 \%$ and the MDD was $1.890 \mathrm{mg} / \mathrm{m} 3$. 
Sustainability, Agri, Food and Environmental Research, (ISSN: 0719-3726), 10(X), 2022:

http://dx.doi.org/

Standard compaction test for soil from Barka Region with $1 \%$ polymer, the OMC was found out to be $14.6 \%$ and the MDD was $1.921 \mathrm{mg} / \mathrm{m}^{3}$. The OMC and MDD values are $13.5 \%$ and $1.963 \mathrm{mg} / \mathrm{m3}$ respectively with $3 \%$ polymer. The OMC and MDD values are $12.6 \%$ and 1.997 The OMC and MDD values are $13.5 \%$ and $1.963 \mathrm{mg} / \mathrm{m} 3$ respectively with $5 \%$ polymer.

\section{d. California Bearing Ratio Test}

The CBR test was done to determine the bearing capacity of the soil. This test has four components. They are with fresh soil and with $1 \%, 3 \%$ and $5 \%$ polymer. The CBR test results are shown in the below tables..

Table 7: CBR test results for Barka Calcareous Soil

\begin{tabular}{lcc}
\hline \multicolumn{2}{l}{ Force of Plunger from Graph (KN) } & \\
\hline Penetration of Plunger & Top Face & Bottom Face \\
$2.5 \mathrm{~mm}$ & 0.7 & 0.8 \\
$5.0 \mathrm{~mm}$ & 1.8 & 1.7 \\
CBR \% Value & & \\
Penetration of Plunger & Top Face & Bottom Face \\
$2.5 \mathrm{~mm}$ (force $\times 100) / 13.2$ & 13.26 & 15.15 \\
$5.0 \mathrm{~mm}$ (force $\times 100) / 20$ & 45.00 & 42.50 \\
\hline
\end{tabular}

Table 8: CBR test result for soil from Barka Region with 1\% addition of Polymer

\begin{tabular}{lcc}
\hline Force of Plunger from Graph $(\mathrm{KN})$ & \\
\hline Penetration of Plunger & Top Face & Bottom Face \\
$2.5 \mathrm{~mm}$ & 0.9 & 1.0 \\
$5.0 \mathrm{~mm}$ & 2.0 & 2.3 \\
CBR \% Value & & \\
Penetration of Plunger & Top Face & Bottom Face \\
$2.5 \mathrm{~mm}$ (force $\times 100) / 13.2$ & 17.05 & 18.94 \\
$5.0 \mathrm{~mm}$ (force $\times 100) / 20$ & 50.00 & 57.5 \\
\hline
\end{tabular}


Sustainability, Agri, Food and Environmental Research, (ISSN: 0719-3726), 10(X), 2022:

http://dx.doi.org/

Table 9: CBR test result for soil from Barka Region with 3\% addition of Polymer

\begin{tabular}{lcc}
\hline Force of Plunger from Graph (KN) & \\
\hline Penetration of Plunger & Top Face & Bottom Face \\
$2.5 \mathrm{~mm}$ & 0.9 & 1.1 \\
$5.0 \mathrm{~mm}$ & 2.3 & 2.4 \\
CBR \% Value & & \\
Penetration of Plunger & Top Face & Bottom Face \\
$2.5 \mathrm{~mm}$ (force $\times 100) / 13.2$ & 17.05 & 20.83 \\
$5.0 \mathrm{~mm}$ (force $\times 100$ ) / 20 & 57.5 & 60.0
\end{tabular}

Table: 10.CBR test result for soil from Barka Region with 5\% addition of Polymer

Force of Plunger from Graph (KN)

\begin{tabular}{lcc}
\hline Penetration of Plunger & Top Face & Bottom Face \\
$2.5 \mathrm{~mm}$ & 1.4 & 1.5 \\
$5.0 \mathrm{~mm}$ & 2.9 & 3.0 \\
CBR \% Value & & \\
Penetration of Plunger & Top Face & Bottom Face \\
$2.5 \mathrm{~mm}$ (force $\times 100) / 13.2$ & 26.52 & 28.41 \\
$5.0 \mathrm{~mm}$ (force $\times 100) / 20$ & 72.50 & 75.00 \\
\hline
\end{tabular}

Discussion

This section of the report will discuss the findings obtained from the soil samples experiments carried out. The first experiment carried out was a sieve analysis. Sieve Analysis test is commonly known as the gradation of particles test. The Sieve Analysis Test carried out on soil from Barka region. Polymer used in this project was in fine such that it passes through a sieve size of $0.063 \mathrm{~mm}$, therefore, the sieve test was not carried out in the treated samples. It was found that the percentage of fine particles (Sand, Silt, and Clay) is higher than the percentage of gravel. The total percentage of sand and silt/clay was found out to be $37 \%$ and $23 \%$ respectively. Therefore, the total percentage of fine particles (Sand, Silt, and Clay) in the examined soil is $60 \%$. Soil with a high percentage of fine particles tend to have a low soil bearing capacity and thus soil stabilization must be carried out in order to increase the bearing capacity of the soil. The specific gravity (pycnometer) test is one of the most important tests, as it is used to calculate the bearing capacity of the 
Sustainability, Agri, Food and Environmental Research, (ISSN: 0719-3726), 10(X), 2022:

http://dx.doi.org/

soil. The test was carried out on 5 different samples and the average was calculated to be used for the research project. The range of specific gravity of Barka region soil was found out to be between 2.59 - 2.63. It was noticed that in this test, the percentage of polymer mixed with the soil- makes no change to the test results, as the water totally interact and mixes with the water particles. Atterberg Limit Test was performed to find out the plasticity index of the soil. The PI of fresh soil from Barka region was found out to be 14.3. It was observed that the addition of polymer to the soil, reduces the PI. The optimum results were found out at $5 \%$ addition of polymer to the fresh soil. The variation in Liquid Limit test shown in Fig1 and the Plastic Limit test shown in Fig 2. It was observed that with the increase of percentage of polymer, the plastic limit and liquid limit values decreased.

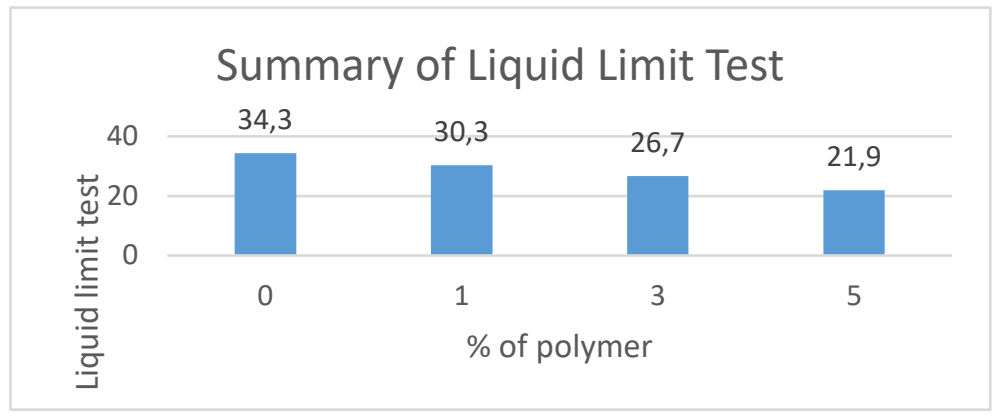

Fig 1: Summary of LL test

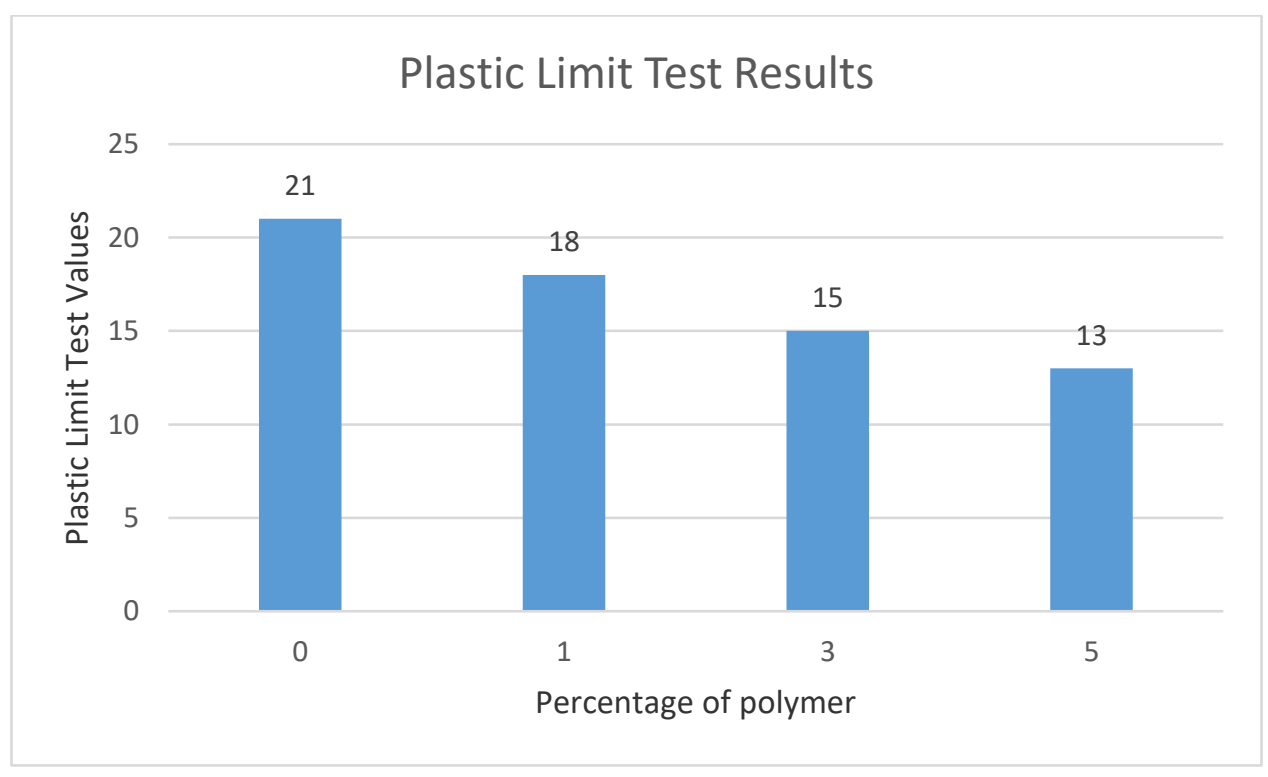

Fig 2: Summary of PL test

The standard compaction test was carried out to see the effect on the OMC and the MDD values. It was observed that the increase of polymer percentage in the treated soil, 
Sustainability, Agri, Food and Environmental Research, (ISSN: 0719-3726), 10(X), 2022:

http://dx.doi.org/

the OMC values decreased and the MDD. Values increased. The results are shown in Fig 3 and Fig 4.

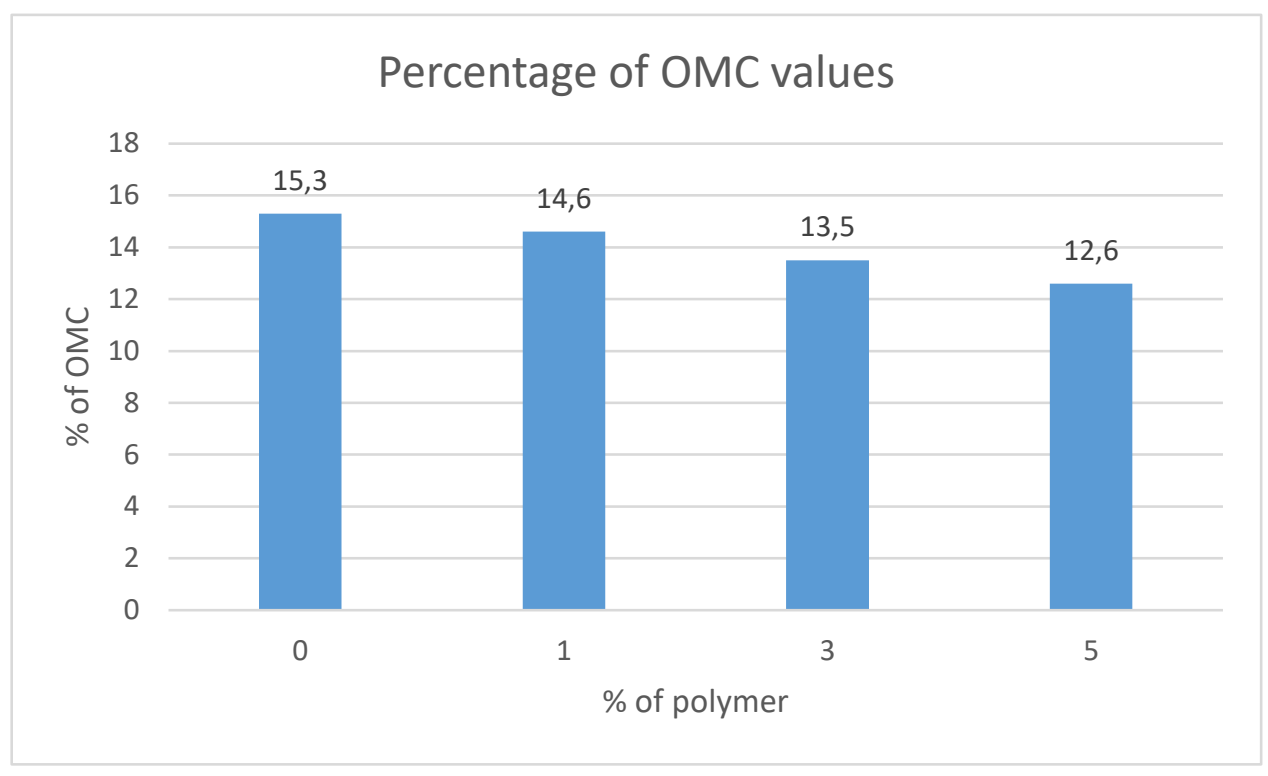

Fig 3: Percentage of OMC values

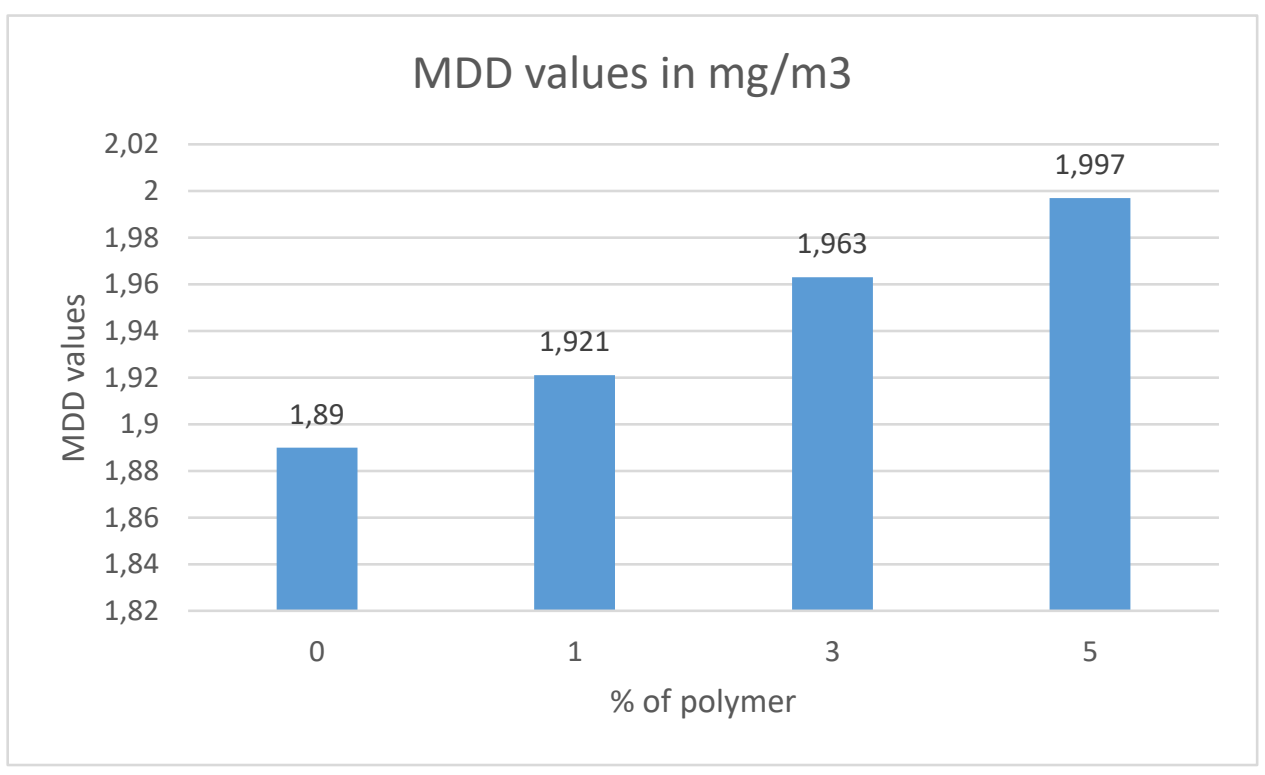

Fig 4: Summary of MDD values

It was found that there is no difference between the tested fresh soil and the treated soil with the polymer in the sieve analysis and specific gravity due to the powder characteristic of polymer (fine particles). Atterberg limit test was utilized to measure the plasticity index. Results showed that the plasticity index of soil mixed with $5 \%$ of polymer 
Sustainability, Agri, Food and Environmental Research, (ISSN: 0719-3726), 10(X), 2022:

http://dx.doi.org/

reduces by $46.6 \%$. In addition, Standard compaction test showed that the OMC values decreases to $2.7 \%$ while MDD values increases by $5.5 \%$, in comparison with the fresh soil and treated soil with $5 \%$ polymer. Finally, CBR test illustrated that the overall bearing capacity increases with the addition of polymer. The soil load bearing capacity increased by adding $5 \%$ polymer. Further study may be continued by increasing the percentage of polymer.

\section{REFERENCES}

Ateş, A., (2013.) The effect of polymer-cement stabilization on the unconfined compressive strength of liquefiable soils. International Journal of Polymer Science, 2-54.

Chao, X., Xueyan, L. and Kumar, A., (2018.) Response of Sandy Soil Stabilized by Polymer Additives. Open Acc J Envi Soi Sci 1 (3)- OAJESS. MS. ID, 112.

Dilip, K.R. and Srinivas, G. Soil stabilization using geopolymer and biopolymer. (2016). Anveshana's international journal of research in engineering and applied sciences. 1(10). 280-289.

Maghchiche, A., Haouam, A. and Immirzi, B., (2010). Use of polymers and biopolymers for water retaining and soil stabilization in arid and semiarid regions. Journal of Taibah University for science, 4(1), 9-16.

Marto, A., Latifi, N. and Sohaei, H., (2013). Stabilization of laterite soil using GKS soil stabilizer. Electronic Journal of Geotechnical Engineering, 18(18), 521-532.

Mirzababaei, M., Arulrajah, A. and Ouston, M., (2017). Polymers for stabilization of soft clay soils. Procedia engineering, 189, 25-32.

Received: $30^{\text {th }}$ January 2021; Accepted: $10^{\text {th }}$ March 2021; First distribution: 01th April 2021 